\title{
Atrazine and burning in tallgrass prairie infested with prairie threeawn
}

\section{DAVID M. ENGLE, TERRENCE G. BIDWELL, JIMMY F. STRITZKE, AND DALE ROLLINS}

\begin{abstract}
Prairie threeawn (Aristida ollgantha Michx.) is an indicator of deteriorated range and is unpalatable and mechanically injurious to livestock. The effects of date of burning (November, February, or April) and atrazine [2-chloro-4-(ethylamino)-6-(isopropylamino)5 -triazine] applied in March at 0 or $1.12 \mathrm{~kg} / \mathrm{ha}$ were evaluated in northcentral Oklahoma on tallgrass prairie hay meadows infested with prairie threeawn. Atrazine provided consistent control of prairie threeawn and increased yield of desirable species in 2 of the 3 studies. Burning in April reduced prairie threeawn in 1 of 3 studies, but burning in February or November did not reduce prairie threeawn in any of the studies. Combining atrazine and burning controlled prairie threeawn no better than atrazine alone when burning was several months before or after application of atrazine. However, burning just 1 month before application of atrazine decreased the activity of atrazine on prairie threenw. Burning alone or burning combined with atrazine did not increase production of desirable species.
\end{abstract}

Key Words: Aristida oligantha Michx., native hay meadow, Oklahoma, range improvement

Prairie threeawn (Aristida oligantha Michx.), also called oldfield threeawn or wire grass, is a $C_{4}$ annual grass that occurs on dry, low fertility sites throughout the eastern one-half of the United States (Hitchcock 1950). The plant is commonly found on abandoned cropland and overgrazed upland range sites (Rice 1968). Prairie threeawn is capable of colonizing bare soil and maintaining dominance for many years because of low nutrient requirements, production of allelochemicals, and low palatability (Rice et al. 1960, Rice 1968, Rice 1971).

Prairie threeawn lowers forage quality where it occurs on

Authors are professor, assistant professor, and professor, Department of Agronomy, Oklahoma State University, Stillwater 74078, and extension wildlife specialist, Texas Agriculture Extension Service, San Angelo 76901. The authors thank Dr. P.L. Claypool for assistance with data analysis. This is journal article 5621 of the Oklahoma Agriculture Experiment Station.

Manuscript accepted 10 January 1990. degraded tallgrass prairie hay meadows and pastures (Booth 1941, Owensby and Launchbaugh 1977) and contains low levels of nitrogen, phosphorus, and calcium during all of its growth stages (Harper et al. 1933). Many tallgrass prairie hay meadows are so heavily infested with prairie threeawn they are not harvested. High silica content of prairie threeawn dulls swathing equipment and impedes hay harvest. The awned seeds of this grass can damage the mouth and entangle the hair of cattle and sheep (Kingsbury 1964, Burrows et al. 1987).

Owensby and Launchbaugh (1977) found that burning before early December in Kansas reduced the number of prairie threeawn seedlings the following growing season. On areas with a residual of perennial plants, reducing prairie threeawn by fall burning increased production of perennial grasses. Cool-season grasses and forbs have been the primary targets of manipulation of herbaceous vegetation in tallgrass prairie through use of both atrazine [2chloro-4-(ethylamino)-6-(isopropylamino)-5-triazine] and late spring burning (Anderson et al. 1970, Baker and Powell 1978, Waller and Schmidt 1983, Towne and Owensby 1984, Gillen et al. 1987). No research has been conducted on atrazine or combinations of dormant season burning and atrazine for manipulating tallgrass prairie infested with prairie threeawn. The objectives of these studies were to determine the effects of atrazine, a dormant season burn, and atrazine and burning in combination on yield of prairie threeawn and desirable forage in tallgrass prairie hay meadows.

\section{Study Area and Methods}

Three studies were conducted on 2 tallgrass prairie hay meadows infested with prairie threeawn. Studies 1 and 2 were conducted 10 km north of Stillwater, Okla., on a Mulhall loam (fine-loamy, siliceous, thermic, Udic Paleustoll) on 3 to 5\% slopes, classified as a Loamy Prairie range site. Study 3 was conducted $5 \mathrm{~km}$ south of Stillwater, Okla., on a Grainola (fine, mixed, thermic Vertic Haplustalf)-Lucien (loamy, mixed, thermic, shallow Typic Haplus- 
Table 1. Dates of treatments and activation of atrazine and years of data collection for the 3 studies.

\begin{tabular}{|c|c|c|c|c|c|c|c|c|}
\hline & \multicolumn{3}{|c|}{ Burning dates } & \multirow{2}{*}{$\begin{array}{c}\text { Atrazine } \\
\text { treatments }\end{array}$} & \multirow{2}{*}{$\begin{array}{c}\text { Estimated } \\
\text { activation } \\
\text { of atrazine }^{1}\end{array}$} & \multicolumn{3}{|c|}{ Yield data } \\
\hline & Nov & Feb & April & & & 86 & 87 & 88 \\
\hline $\begin{array}{l}\text { Study } 1 \\
\text { Study } 2 \\
\text { Study } 3\end{array}$ & $\begin{array}{l}-\overline{1}-\frac{2}{11 / 20 / 86} \\
11 / 20 / 86\end{array}$ & $\begin{array}{l}2 / 2 / 86 \\
2 / 3 / 87 \\
2 / 3 / 87\end{array}$ & $\begin{array}{l}4 / 9 / 86 \\
4 / 8 / 87 \\
4 / 8 / 87\end{array}$ & $\begin{array}{l}3 / 21 / 86 \\
3 / 11 / 87 \\
3 / 11 / 87\end{array}$ & $\begin{array}{l}4 / 3 / 86 \\
3 / 17 / 87 \\
3 / 17 / 87 \\
\end{array}$ & $\mathbf{X}$ & $\begin{array}{l}\mathbf{X} \\
\mathbf{X} \\
\mathbf{X}\end{array}$ & $\mathbf{x}$ \\
\hline
\end{tabular}

'Date on which precipitation in a single event exceeded $2.5 \mathrm{~cm}$.

${ }^{2}$ No burn in November in study 1 .

toll) complex with 1-5\% slopes, classified as a Shallow Prairie range site (USDA Soil Conservation Service 1987). The potential grassland community on both range sites would be dominated by big bluestem (Andropogon gerardii Vitman), little bluestem (Schizachyrium scoparium Michx.), switchgrass (Panicum virgatum L.), and indiangrass [Sorghastrum nutans (L.) Nash]. Hay had been harvested annually from both locations in years previous to initiation of these studies. Herbage was cut for hay on both locations in mid-July each year during the studies.

Each study was designed as a randomized complete block with a factorial arrangement of treatments having 4 replications per treatment (Table 1). Factors were burning date and atrazine (no atrazine or atrazine at $1.12 \mathrm{~kg} / \mathrm{ha}$ ). Burning dates and dates of atrazine application are listed in Table 1. Plots in all studies were 10 $\times 10 \mathrm{~m}$. November burns were conducted shortly after warmseason tallgrasses became dormant in the fall, February burns were in late winter before tallgrasses began growth, and April burns coincided with renewed growth of tallgrasses (new tillers 2 to $5 \mathrm{~cm}$ in height) in late spring. Plots were burned with headfires ignited at plot boundaries with a drip torch. Weather and fuel conditions for each burn date and study are listed in Table 2.

The response of prairie threeawn and other herbage components to treatments was determined by clipping in mid-summer (late June or early July). In addition, the residual treatment effects in studies 1 and 3 were assessed by clipping herbage in mid-summer the second year (Table 1). Herbage was clipped to ground level in 5 , $0.5 \times 0.2-\mathrm{m}$ quadrats within each plot and separated into current year's herbage and old herbage (litter and mulch). Current year's herbage was separated into tallgrasses, little bluestem, other perennial grasses, prairie threeawn, and forbs. Herbage was dried at $65^{\circ} \mathrm{C}$ for $72 \mathrm{hr}$ and weighed. For data analysis all current year's herbage components, other than prairie threeawn, were combined into 1 category which we term desirable hay species. Forbs composed 2 to $14 \%$ by weight of the total herbage composition in the 3 studies. Repeated measurements in studies 1 and 3 were randomized with restriction to prevent sampling of areas that were clipped the previous year.

Analysis was as suggested by Carmer et al. (1989) for factorial, split-plot designs except that years, as the split-plots, were nested within studies. Main factors were treatments and studies. Because of the unbalanced design we used the Type I sum of squares in the SAS PROC GLM (SAS 1985). The least significant difference test protected by a significant $(P<0.05)$ F-test was used to test differences among means (Steele and Torrie 1960).

\section{Results and Discussion}

Monthly and cumulative precipitation up to clipping (vegetationyear-precipitation) varied during the study, but vegetation-year precipitation was near average in the first and third years of the study and above average in the second year of the study (Table 3 ).

Table 3. Vegetntion-year (November to June) precipitation (mm) up to time of hay harvest in tallgrass prairie and long-term average precipitation at Stillwater, Okbhoma.

\begin{tabular}{lcccc}
\hline \hline Month & \multicolumn{3}{c}{ Year } & Long-term \\
\cline { 2 - 4 } average
\end{tabular}

Large monthly differences among years occurred in May and June, the period of peak precipitation as well as the period of most rapid herbage growth rate in tallgrass prairie (Gillen and McNew 1987). Precipitation was below average during May and June 1988.

\section{Prairie Threeawn}

The interaction of atrazine, burn, and year with study was significant $(P<0.01)$. Further analysis within studies showed the atrazine $X$ burn $X$ year interaction was significant in study 1 $(P<0.01)$, which we attribute to less standing crop of prairie threeawn in the check plots (no atrazine and no burn) in 1987 $(3,010 \mathrm{~kg} / \mathrm{ha}$ in $1986 \mathrm{compared}$ to $340 \mathrm{~kg} / \mathrm{ha}$ in 1987$)$. The atrazine $\times$ burn $X$ year interaction was not significant $(P>0.56)$ in study 3 . Production of prairie threeawn fluctuated greatly from year to year. Standing crop of prairie threeawn on untreated plots in the first year of the studies varied from $520 \mathrm{~kg} /$ ha (study 2) to 3,010 $\mathrm{kg} / \mathrm{ha}$ (study 1).

Atrazine reduced prairie threeawn in all studies. Atrazine without burning and atrazine with an April burn reduced prairie threeawn in the first year of study 1 (Table 4). However, plots treated with atrazine following a February burn produced more prairie threeawn (Table 4), which we attribute to carbon inactivation of atrazine in the ash (Jordon and Smith 1971). Atrazine-

Table 2. Fuel and weather conditions associated with burning treatments. Fuel measurements are means and atandard errors ( $\mathrm{n}=10$ ).

\begin{tabular}{|c|c|c|c|c|c|c|c|c|}
\hline & \multicolumn{2}{|c|}{ Study 1} & \multicolumn{3}{|c|}{ Study 2} & \multicolumn{3}{|c|}{ Study 3} \\
\hline & Feb & April & Nov & Feb & April & Nov & Feb & April \\
\hline $\begin{array}{l}\text { Air temperature }\left({ }^{\circ} \mathrm{C}\right) \\
\text { Relative humidity }(\%) \\
\text { Windspeed }(\mathrm{km} / \mathrm{h}) \\
\text { Fuel loading }(\mathrm{kg} / \mathrm{ha}) \\
\text { Fuel moisture }(\%)\end{array}$ & $\begin{array}{c}24 \\
53 \\
10 \\
2600 \pm 300 \\
12 \pm 1\end{array}$ & $\begin{array}{c}18 \\
28 \\
10 \\
1530 \pm 360 \\
45 \pm 3\end{array}$ & $\begin{array}{c}18 \\
33 \\
18 \\
2700 \pm 150 \\
33 \pm 1\end{array}$ & $\begin{array}{c}17 \\
26 \\
10 \\
2500 \pm 300 \\
52 \pm 6\end{array}$ & $\begin{array}{c}26 \\
20 \\
10 \\
1770 \pm 340 \\
28 \pm 2\end{array}$ & $\begin{array}{c}18 \\
33 \\
10 \\
2990 \pm 200 \\
34 \pm 1\end{array}$ & $\begin{array}{c}19 \\
30 \\
6 \\
3000 \pm 550 \\
60 \pm 12\end{array}$ & $\begin{array}{c}25 \\
21 \\
10 \\
2240 \pm 280 \\
22 \pm 2\end{array}$ \\
\hline
\end{tabular}


Table 4. Standing crop (kg/ha) of prairie threenwn on tallgrass prairies following burning and atrazine treatments in the first year of Study 1.

\begin{tabular}{lrc}
\hline \hline & \multicolumn{3}{c}{ Atrazine (kg/ha) } \\
\cline { 2 - 3 } Burn date & 0 & 1.1 \\
\hline None & 3010 & 100 \\
February & 2800 & 770 \\
April & 660 & 110 \\
& \multicolumn{3}{c}{ OSL $=0.011$} & \\
& \multicolumn{3}{c}{ LSD $_{0.05}=360$} \\
\hline
\end{tabular}

'Observed significance level.

treated plots in the second year of study 1 had less $(P<0.05)$ prairie threeawn than plots not treated with atrazine (330 verses 620 $\mathrm{kg} / \mathrm{ha})$. Atrazine-treated plots also had less $(P<0.04)$ prairie threeawn than plots not treated with atrazine in studies 2 and $3(140$ $\mathrm{kg} / \mathrm{ha}$ compared to $370 \mathrm{~kg} / \mathrm{ha}$ averaged over burning date in study 2 and $230 \mathrm{~kg} / \mathrm{ha}$ compared to $430 \mathrm{~kg} / \mathrm{ha}$ averaged over years and burning date in study 3 ).

On plots not treated with atrazine, prairie threeawn standing crop was less in plots burned in April than in either unburned plots or plots burned in February in the first year of study 1 (Table 4). Burning at any date did not reduce standing crop of prairie threeawn below that in the unburned plots in the second year of study 1 and in studies 2 and 3 (Table 5). Prairie threeawn standing crop was greater on the plots burned in February compared to plots burned in April in the second year of study 1 and in study 3 (Table 5).

Table 5. Standing crop (kg/ha) of prairie threeawn on tallgrass prairies following burning treatments in the second year of study 1 and in study 2 , averaged over atrazine treatments, and in study 3 , averaged over atrazine treatments and years.

\begin{tabular}{|c|c|c|c|}
\hline & Study 1 & & Study 3 \\
\hline Burn date & Year 2 & Study 2 & Years $1 \& 2$ \\
\hline $\begin{array}{l}\text { None } \\
\text { November } \\
\text { February } \\
\text { April }\end{array}$ & $\begin{array}{c}340 \\
-840 \\
240 \\
O S L=0.01^{2} \\
\operatorname{LSD}_{0.06}=350\end{array}$ & $\begin{array}{c}300 \\
180 \\
440 \\
120 \\
\text { OSL }=0.08\end{array}$ & $\begin{array}{c}380 \\
250 \\
590 \\
120 \\
O S L=0.01 \\
\mathrm{LSD}_{0.05}=330\end{array}$ \\
\hline
\end{tabular}

'No November burn in study 1 .

2Observed significance level.

Owensby and Launchbaugh (1977) found that prairie threeawn was reduced by fall burning but not by spring burning. We found no difference in prairie threeawn standing crop between November and April burning treatments (Table 5). Fires on these 2 burning dates were conducted under similar fuel and weather conditions (Table 2), and fire behavior appeared to differ little among the burns, so we believe the direct effects of the fires on prairie threeawn were also similar. The reduction of prairie threeawn after fall burning was attributed by Owensby and Launchbaugh (1977) to mulch removal. We believe that because the seedbank of coolseason annual grasses is reduced by September burning (Ewing and Engle 1988), it is possible that November burning may reduce the prairie threeawn seedbank if inflorescences are intact or seed rest in a dry mulch layer and are consumed by the fire. Burns that occur later in the dormant season may not reduce seedbanks if seed are buried after falling to the ground or if seed escape damage from the fire by residing in a moist mulch layer. This may be the reason prairie threeawn was not reduced by burning in February. The difference in prairie threeawn response to spring burning between Owensby and Launchbugh's study and our study may be that our spring burns were applied at a later phenological stage of prairie threeawn, possibly after more prairie threeawn seedlings had emerged. Discrepancies among studies on the effects of fire within the same season on species composition in tallgrass prairie are likely the result of differences in time of burning of only a few weeks (Towne and Owensby 1984).

\section{Desirable Hay Species}

The interaction of atrazine, burn, and year with study was significant $(P<0.02)$. Further analysis within studies showed the atrazine $X$ burn $X$ year interaction was significant in study 1 $(P<0.02)$ but not in study $3(P>0.41)$. Atrazine and burning did not interact $(P>0.05)$ in any of the 3 studies. Standing crop of desirable hay species was greater $(P<0.01)$ in plots treated with atrazine in the first year of study 1 and in the second year of study 3

Table 6. Standing crop (kg/ha) of desirable hay species on tallgrass prairies following atraxine treatments. Values are averaged over burning treatments.

\begin{tabular}{|c|c|c|c|c|}
\hline \multirow[b]{2}{*}{ Study } & \multirow[b]{2}{*}{ Year } & \multicolumn{3}{|c|}{ Atrazine (kg/ha) } \\
\hline & & 0 & & 1.1 \\
\hline 1 & 1 & 1870 & $\begin{array}{l}O S L=0.01^{1} \\
L^{\prime} D_{0.05}=290\end{array}$ & 3040 \\
\hline & 2 & 2020 & $\mathrm{OSL}=0.81$ & 2270 \\
\hline 2 & 1 & 1650 & $\mathrm{OSL}=0.22$ & 1740 \\
\hline 3 & 1 & 1440 & $\mathrm{OSL}=0.56$ & 1630 \\
\hline & 2 & 1610 & $\begin{array}{l}\mathrm{OSL}=0.01 \\
\mathrm{LSD}_{0.06}=180\end{array}$ & 1940 \\
\hline
\end{tabular}

'Observed significance level.

(Table 6). Similar increases in yields of warm-season grasses following application of atrazine to control forbs and cool-season annual grasses have been previously reported (Baker and Powell 1978, Waller and Schmidt 1983, Rehm 1984, Gillen et al. 1987). We attribute lack of response of desirable hay species after application of atrazine in the first year of study 3 and in study 2 to a combination of an overall decrease in standing crop of prairie threeawn and an overall decrease in total standing crop in 1987.

Late-spring burning generally favors tallgrasses, and increased herbage production from late spring burning may also occur on sites with excessive mulch accumulation (Graves and McMurphy 1969, Anderson et al. 1970, Powell et al. 1979, Towne and Owensy 1984). Burning in seasons other than late spring may actually decrease herbage and tallgrass yields (Towne and Owensby 1984). In our studies, yield of desirable hay species were not increased with any burning treatment (Table 7). This agrees with the results of Gillen et al. (1987), who found burning or burning combined with atrazine did not increase herbage yield in low-seral communities.

Fall burning has been shown to increase the yield of tallgrasses the following growing season on a site heavily infested with prairie threeawn (Owensby and Launchbaugh 1977). Graves and McMurphy (1969) also found that yield of desirable grasses increased in a pasture infested with prairie threeawn after 2 successive burns with a backfire in early April and $21 / 2$ years of rest from grazing. This suggests that burning treatments could both increase production of desirable species and decrease production of prairie threeawn. None of our burning treatments, however, resulted in any significant increase in production of desirable hay species. 
Table 7. Standing crop (kg/ha) of desirable hay species on tallgrass prairies following burn treatments. Values are averaged over atrazine treatments.

\begin{tabular}{|c|c|c|c|c|c|}
\hline \multirow[b]{2}{*}{ Study } & \multirow[b]{2}{*}{ Year } & \multicolumn{4}{|c|}{ Burn date } \\
\hline & & None & November & February & April \\
\hline \multirow[t]{3}{*}{1} & 1 & 2760 & -1 & 2220 & 2390 \\
\hline & & & & & \\
\hline & 2 & 2260 & -- & 1990 & 2180 \\
\hline 2 & 1 & 2060 & 1650 & $\begin{array}{r}1500 \\
45\end{array}$ & 1590 \\
\hline 3 & & 1680 & 1820 & 1470 & 1780 \\
\hline
\end{tabular}

INo November burn in study 1.

2 Observed significance level.

${ }^{3}$ Burn $X$ year was not significant for study $3(P>0.10)$ so values are averages of year 1 and 2 .

\section{Management Implications}

Atrazine effectively controlled prairie threeawn and sometimes increased desirable hay species on tallgrass prairie hay meadows. Hay meadows that are annually harvested usually have little litter to reduce forage quality, so burning or combining burning with atrazine to control prairie threeawn offers little advantage over atrazine alone applied in March. Burning preceding application of atrazine should be discouraged because herbicide activity may be reduced with carbon deactivation of atrazine.

Managers could use November or April burning as an alternative for reducing prairie threeawn if the objective is to simply reduce prairie threeawn to a level under which harvest is possible. However, repeated April burning as demonstrated by Graves and McMurphy (1969) would be required to provide long-term control of prairie threeawn.

\section{Literature Cited}

Anderson, K.L., C.E. Owensby, and E.F. Smith. 1970. Burning bluestem range. J. Range Manage. 23:81-92.

Baker, R.L., and J. Powell. 1978. Oklahoma tallgrass prairie responses to atrazine with 2,4,-D and fertilizer. Proc. First Internat. Rangeland Cong. p. 681-683.

Booth, W.E. 1941. Revegetation of abandoned fields in Kansas and Oklahoma. Amer. J. Bot. 28:415-422.
Burrows, G.E., R.J. Tyrl, D. Rollins, T.R. Thedford, W.E. McMurphy, and W.E. Edwards. 1988. Toxic plants of Oklahoma and the southern plains. Oklahoma State Coop. Ext. Serv. E-868, Stillwater.

Carmer, S.G., W.E. Nyquist, and W.M. Walker. 1989. Least significant differences for combined analyses of experiments with two- and threefactor treatment designs. Agron. J. 81:665-672.

Ewing, A.L., and D.M. Engle. 1988. Effects of late summer fire on tallgrass prairie microclimate and community composition. Amer. Midl. Nat. 120;212-223.

Gillen, R.L., and R.W. McNew. 1987. Seasonal growth rates of tallgrass prairie after clipping. J. Range Manage. 40:342-345.

Gillen, R.L., D. Rollins, and J.F. Stritzke. 1987. Atrazine, spring burning, and nitrogen for improvement of tallgrass prairie. J. Range Manage. 40:444-447.

Graves, J.E., and W.E. McMurphy. 1969. Burning and fertilization for range improvement in central Oklahoma. J. Range Manage. 22:165-168.

Harper, H.J., H.A. Daniel, and H.F. Murphy. 1933. The total nitrogen, phosphorus, and calcium content of common weeds and native grasses in Oklahoma. Proc. Oklahoma Acad. Sci. p. 36-44.

Hitchcock, A.S. 1950. Manual of the grasses of the United States. USDA Misc. Pub. 200.

Jordon, P.D., and L.W. Smith. 1971. Adsorption and deactivation of atrazine and diuron by charcoals. Weed Sci. 19:541-544.

Kingsbury, J.M. 1964. Poisonous plants of the United States and Canada. Prentice-Hall, Inc., Englewood Cliffs, N.J.

Owensby, C.E., and J.L. Launchbaugh. 1977. Controlling prairie threeawn (Aristida oligantha Michx.) in central and eastern Kansas with fall burning. J. Range Manage. 30:337-339.

Powell, J., H.T. Zawi, J.J. Crockett, L.I. Croy, and R.D. Morrison. 1979. Central Oklahoma rangeland response to fire, fertilization, and grazing by sheep. Oklahoma Agr. Exp. Sta. Bull. B-744.

Rehm, G.W. 1984. Yield and quality of warm-season grass mixture treated with N, P, and atrazine. Agron. J. 76:731-733.

Rice, E.L., W.T. Penfound, and L.M. Rohrbaugh. 1960. Seed dispersal and mineral nutrition in succession in abandoned fields in central Oklahoma. Ecology 41:224-228.

Rice, E.L. 1968. Inhibition of nodulation of inoculated legumes by pioneer plant species from abandoned fields. Bull. Torrey Bot. Club 95:346-358.

Rice, E.L. 1971. Inhibition of nodulation on inoculated legumes by leaf leachates from pioneer plant species from abandoned fields. Amer. J. Bot. 58:368-371.

SAS. 1985. SAS user's guide: Statistics. SAS Institute. Cary, N.C.

Steele, R.G.D., and J.H. Torric. 1960. Principles and procedures of statistics. McGraw-Hill Book Co., New York.

Towne, G., and C. Owensby. 1984. Long-term effects of annual burning at different dates in ungrazed Kansas tallgrass prairie. J. Range Manage. 37:392-397.

USDA Soil Conservation Service. 1987. Soil survey of Payne County, Oklahoma. Soil Cons. Serv., USDA.

Waller, S.S., and D.K. Schmidt. 1983. Improvement of eastern Nebraska tallgrass range using atrazine or glyphosate. J. Range Manage. 36:87-90. 